\title{
Implementing the Service Concept through Value Engineering
}

\author{
Alastair Nicholson ${ }^{1}$ and Katarzyna Zdunczyk ${ }^{2}$ \\ 1) London Business School, Department of Operations and Technology Management, Sussex \\ Place, London NWI 4SA, United Kingdom. \\ Email: anicholson@london.edu. \\ 2) Warsaw University of Technology Business School, ul. Koszykowa 79, 02-008 Warszawa, \\ Poland. \\ Email: k.zdunczyk@business.edu.pl.KAP
}

\begin{abstract}
As products have become commoditised and technology knowledge made available to all, the possession of customers has become crucially dependent on the service content of what is delivered. Initially service was seen as an add-on aspect of business and to be highly personalised to customers and employees alike. But the significance of service to justify price, to support brand, to enrich the product, even to learn about the customer, means that the service concept and the service delivery must be managed even if such management is much less well defined than physical product and process management. This paper sets out to establish the possibility of designing both the content of service value and the service system which is needed to provide it. Following the analysis of service itself, the paper identifies the tools needed to engineer the service system to inspect it and position it within the commercial scheme. The McDonald's operation and others will be used to illustrate the concepts and their application. The principle of effective design and evaluation will be stated and defended as the fundamental means of achieving the value of service to both clients and the providing company. The conditions for successful adoption of the principles will be identified.
\end{abstract}

Key words: Service delivery system, Service design, Service value, Service process engineering 


\section{THE CHALLENGE OF SERVICE ENGINEERING}

Most Western economies are now called "service" economies. As pointed out by FITZSIMMONS (1994), the percentage of employment in service roles increased to $78 \%$ by 1992 . The service economy, now becoming extended to the experience economy, is dominated by organisations which process customers rather than materials. This provokes a new set of challenges:

- of how to define what customers expect and want when that definition depends on the current circumstances which the customer finds themselves in;

- of how to provide the service economically (profitably) when only a few parts of the service can be charged for;

- of how to manage employees who are the fundamental service providers in a situation where we want both consistency overall and individuality as needed.

In fact, the challenges are not new. The great body of human work in engineering companies has always been service - supplied internally or externally in information, discussion, and interpretation. It is the formal accounting system which does not classify outputs into service content and making content. Now most of the banks and call centres are much more like factories in their behaviour than manufacturers who are keenly engaged in design discussion and after sales service.

What is new is the idea of managing service in a systematic way rather than in an ad-hoc way. The significance and pervasiveness of service makes it critical that it is managed and that requires a "model" of how it works, how the trade-offs involved are resolved, and how it leads to success. The starting point is to recognise service provision in terms of two loosely coupled systems:

- the customer satisfaction system;

- the service delivery system.

Unlike product manufacture (or product provision) the service system requires that satisfaction and provision take place concurrently and against undefined specification. In product provision, the terms of what is provided are defined in advance and any failure is debated around a specification which is broadly "on the producer's side". In the service system the customers move from expectations to satisfaction on their own terms. Although we may estimate both expectations and satisfaction, they are at best guesses.

The service delivery system is not a making process: it is a context within which the customer can acquire the elements of service wanted. Physically, 
it is buildings, atmosphere, and responsiveness of employees. It is an offer; it requires specification without knowing how precisely it could be specified. The art of service engineering is to steer the customer towards the service delivery system and steer the service delivery system towards the customer. It is an art rather than a science - but it is by implication a design and it can be monitored. The next two sections will explore these two interrelated transformations.

\section{GIVING MEANING TO THE SERVICE VALUE}

Although the customer may regard the service delivered in rather abstract terms such as responsiveness, courtesy, competence, etc., these attributes of service value must be acquired through the experience which customers have in passing through the service delivery system. They will often be acquired subconsciously but nevertheless valued for it. The service provided must therefore translate the specific encounters during that experience into factors which can be created and managed.

Taking the familiar example of McDonald's fast food chain, they stated their intention of delivering a service concept (SLACK et al. 1998). The concept was embodied in four criteria: quality, service, cleanliness and value. These are general terms but the ideas are vivid. By service the McDonald's organisation understood speed. Of course, representing a fast food chain, speed is of the essence. But by delivering more than speed they were adding to the total service package being delivered. They were adding quality - a necessity in food delivery, cleanliness - which is a surprise to the customer, and value - a more general term meaning, one suspects, getting a satisfaction at which the price is sufficiently low not to be questioned.

Some of these criteria could be discussed with customers, like the precise meaning of cleanliness: no litter, clean windows, clean uniforms. But McDonald's had no intention of pre-specifying what cleanliness meant to the customer. Cleanliness was something which satisfied and pleased as part of the experience. The required "outputs" from the service system are "qualities" which create the end customer value which, in turn, makes up the satisfaction.

The "black box" of the service system must embrace the service value content by the way it can operationalise the service experience. The scheme is illustrated in Figure 1, which shows customer expectations being connected into satisfaction by the way the mechanism of the service delivery system works. 
Let it be stressed again that we have little direct control over either expectations or satisfaction. Both are unknown. Of course, we can influence the expectations through marketing - certainly for new customers - and we can apparently analyse satisfaction through questionnaires. But both these connections are suspect. However much we try, individual customers will misunderstand the marketing statement and customer feedback is notoriously biased towards complaints and not compliments. Therefore we have to take a view on how to identify and organise the service elements prior to designing the service delivery system.

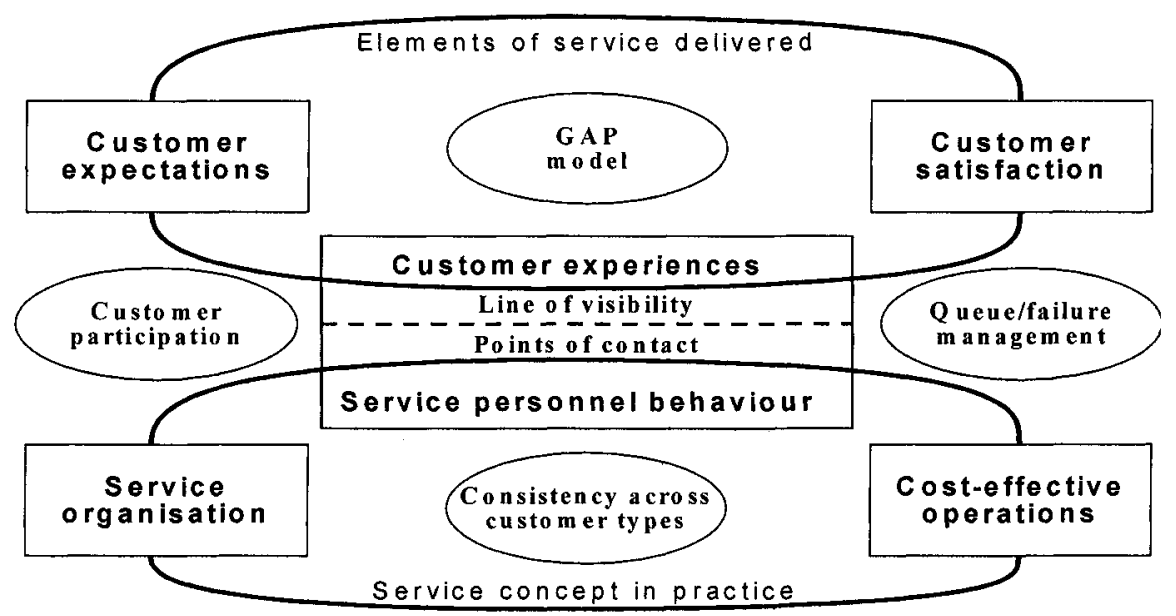

Figure 1. The service delivery system

\section{THE CHALLENGE OF IDENTIFYING SERVICE REQUIREMENTS}

The delivery of service satisfaction is much more obscure than the delivery of product satisfaction, which will be only approximately known at best. The requirement is to at least meet customers' expectations - expectations which are determined by previous experiences, and marketing statements. But here again expectations cannot realistically or sensibly be analysed in depth in advance. Thus the providers of service are caught in the trap of:

- engineering a service providing system

- without a definition of requirements

- which works on a concurrent creation and fulfilment of service needs 
- capable of having standards but adapting to individual needs.

The first step towards defining requirements is to recognise all the elements which may form part of the satisfaction package. The package of value can be related to properties of the package such as: appearance, reliability, responsiveness, competence, and quality of the overall experience. The actual elements or encounters which create the impression and reality of that experience can then be identified in a list of factors which the service experience provides. The elements can now be classified into four categories: tangible, intangible (on whether the element is "acquired" directly by the customer); explicit, implicit (officially stated by the organisation or just assumed). See Figure 2 for an example set of elements from a hospital which specialises in hernia operations.

\begin{tabular}{|c|c|c|}
\hline & Explicit & Implicit \\
\hline $\begin{array}{l}\frac{0}{0} \\
\frac{\sigma}{\sigma} \\
\frac{\Gamma}{\sigma}\end{array}$ & $\begin{array}{l}\text { Specialised in external } \\
\text { hernia operations } \\
\text { - Unique technique with } \\
\text { highest success rate } \\
\text { - Low total cost to patient }\end{array}$ & $\begin{array}{l}\text { - Pleasant location and } \\
\text { premises } \\
\text { - Common meals prepared } \\
\text { from fresh ingredients } \\
\text { - Roommates chosen to have } \\
\text { similar backgrounds/interests }\end{array}$ \\
\hline 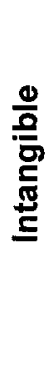 & $\begin{array}{l}\text { - Painless experience } \\
\text { - Quick recovery } \\
\text { - Patient physically and } \\
\text { psychologically well } \\
\text { throughout the experience. }\end{array}$ & $\begin{array}{l}\text { - Socialising with other patients } \\
\text { and staff } \\
\text { - "Country-club" atmosphere } \\
\text { - Outdoor and indoor activities } \\
\text { available } \\
\text { - Patients treated like partners } \\
\text { in the process } \\
\text { - Sense of belonging to a } \\
\text { community }\end{array}$ \\
\hline
\end{tabular}

Figure 2. Elements of value - hernia hospital

The usefulness of making this classification is that it helps to identify all the elements which may contribute to satisfaction and it helps to link rather general abstract notions of satisfaction into specific characteristics of the service system. But the more fundamental advantage is that it provides a structure within which the organisation can manage the transformation of expectations into satisfaction. The elements which form the tangible and 
explicit are classically the factors which determine the official statement called "the service offer": the declared promise to the customer.

The tangible, implicit elements will typically be forced upon the organisation by circumstances and the intangible, implicit will be forced upon the organisation by competitors' practices. However, the transformation of expectations into satisfaction will be mostly achieved through the intangible, implicit elements which capture the mind of the customer as additional value wherein the whole "value for money" deal is fulfilled in a way which is private to both parties.

The challenge now is to create a service delivery system - a context and a set of working practices through which the satisfaction is generated.

\section{THE CONSTRUCTION OF THE SERVICE DELIVERY SYSTEM}

The differences between organisation of products and organisation of service is equally significant. For product manufacture we define technical processes for creating the object to tolerances which can be agreed and research matching options for reliability, volume and speed. The same broad results are being achieved, but in the service system we are not buying the machinery to achieve the transformation, we are creating a context within which the transformation can happen of its own accord. We are not processing the physical object to create a form or shape with properties which in use will serve a purpose. It is the perspective of the customer him/herself which is being transformed and which is the material, the machine and the end result!

Organising the conditions for successful service transformation is enabled through several major influencing variables:

- the facilities themselves, their décor, and their use of space,

- the employees, their standards, behaviours and responsiveness,

- the use of technologies and information, and

- the presence of other customers - both negatively and positively.

Organising the service system for effectiveness as a design for conditioning the transformation has several key technical properties which can be managed and indeed designed to create success:

- selection of appropriate "points of contact" where customers and the organisation interact,

- provision of the line of visibility, line of interaction and line of intervention where the customer can penetrate the organisation as appropriate, 
- customer participation where the customer can become part of the contribution to the process,

- channelling of customers for differentiation of needs and effectiveness, and

- locating the points where queues of customers may develop and planning the means of avoiding queues (demand-supply management) or addressing the queue as a part of the experience.

Few organisations have pursued these distinguishing factors for designing effective service systems despite the broad recognition of the importance of service. But perhaps most significantly it is precisely through these factors that the current practices of an organisation can be investigated.

We will illustrate some of these themes as they apply to two organisations - McDonald's fast food and the hernia hospital referred to earlier. But first it is worth considering the steps which the customer (or customers) are likely to go through. This enables the recognition of the opportunities for value acquisition and service delivery. Such diagrams tracking a customer through service look no different from the process flow diagrams used for engineered products. See for example Figure 3 which shows the process flow of a patient through the hospital treatment for a hernia.

But such a process flow is not the design, it is the analysis of steps which the customer makes in using the design. The design is the physical layout, the atmosphere, the environment, the selection of points for employee encounter, the signage and the assisting technologies. This provides the architecture of a potential working design. And that design may have to accommodate very different customers, i.e. the same facilities may have to be viewed very differently by different groups. This is illustrated in Table 1 which shows how the facilities in a hotel may be recognised very differently by different customer groups. The process flow diagram thus is not a design but a means of knowing what possibilities of encounters exist. We do not derive the 'product', i.e. service value from this: we derive the possibilities for the customer to recognise the service. 

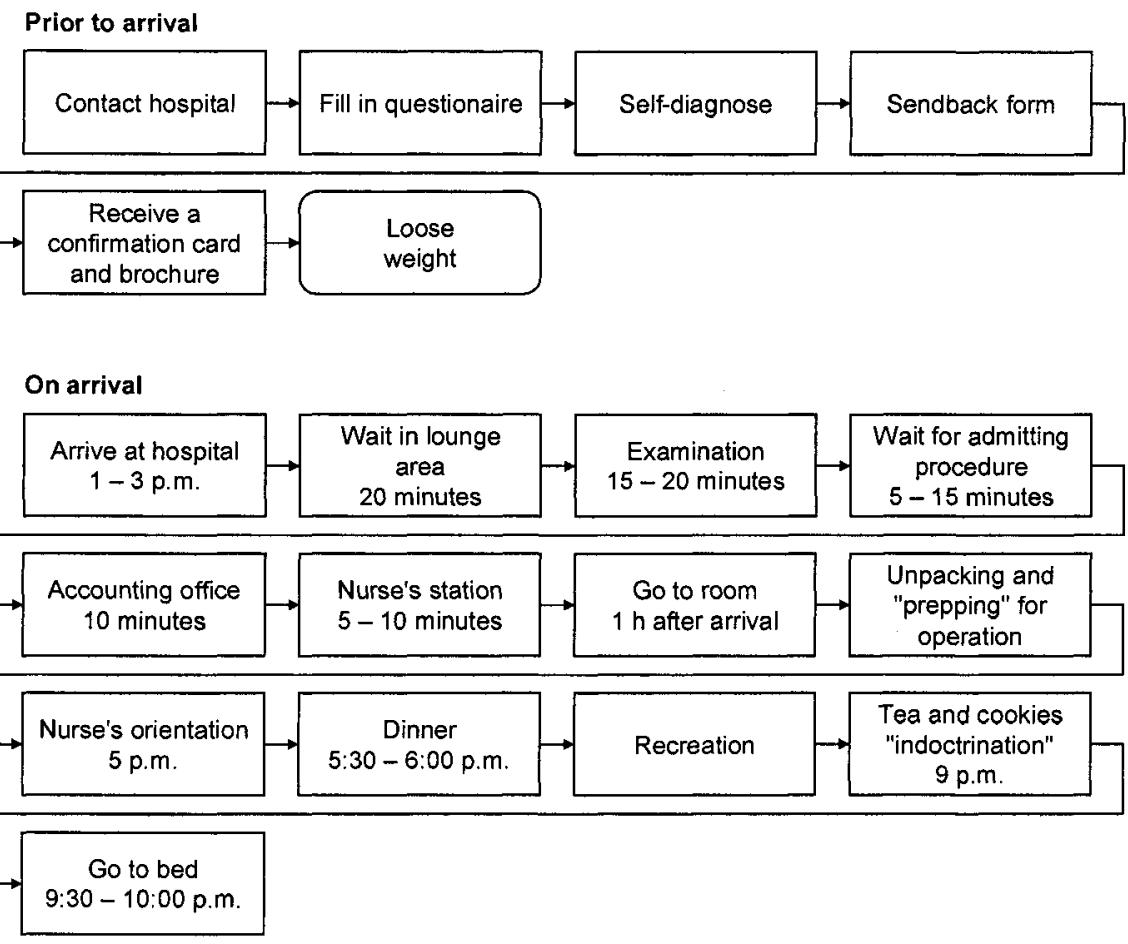

\section{Day of operation}

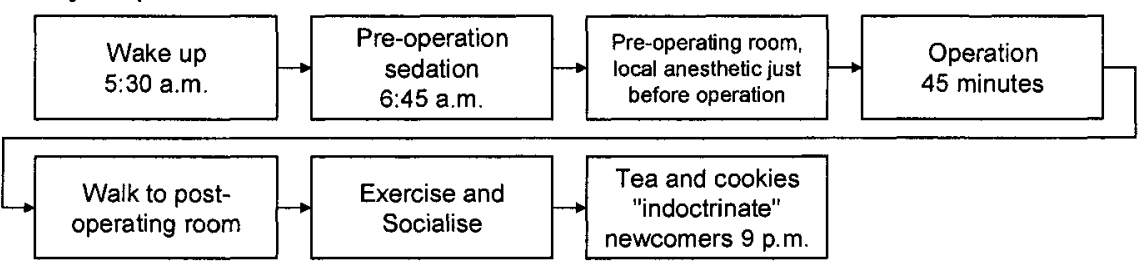

The following two days

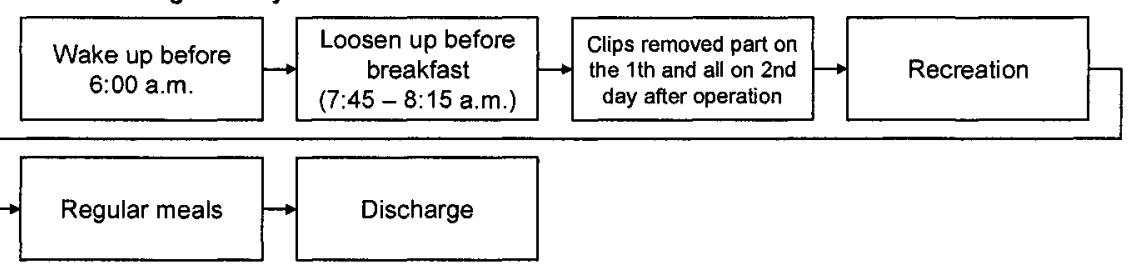

Figure 3. Customer progression through the system - hernia hospital 
Table 1. Hotel service as viewed by different customer groups

\begin{tabular}{|c|c|c|c|c|}
\hline Process & $\begin{array}{c}\text { Business } \\
\text { traveller }\end{array}$ & $\begin{array}{c}\text { Wealthy } \\
\text { tourist }\end{array}$ & $\begin{array}{c}\text { Romantic } \\
\text { break }\end{array}$ & $\begin{array}{c}\text { Function } \\
\text { room }\end{array}$ \\
\hline $\begin{array}{l}\text { Telephone } \\
\text { to make } \\
\text { reservation }\end{array}$ & $\begin{array}{l}\text { Efficiency, } \\
\text { Interested in } \\
\text { corporate rates }\end{array}$ & Polite services & $\begin{array}{l}\text { Special } \\
\text { weekend } \\
\text { rates, } \\
\text { Complimentary } \\
\text { champagne }\end{array}$ & $\begin{array}{l}\text { Precise } \\
\text { details of } \\
\text { room speci- } \\
\text { fication }\end{array}$ \\
\hline $\begin{array}{l}\text { Arrive at } \\
\text { hotel }\end{array}$ & $\begin{array}{l}\text { Easy/fast } \\
\text { access from } \\
\mathrm{road} / \mathrm{rail} / \mathrm{air}\end{array}$ & $\begin{array}{l}\text { Easy/fast } \\
\text { access from } \\
\text { road/rail/air }\end{array}$ & $\begin{array}{l}\text { First impres- } \\
\text { sions impor- } \\
\text { tant }\end{array}$ & $\begin{array}{l}\text { Clear sign- } \\
\text { posting }\end{array}$ \\
\hline Check-in & $\begin{array}{l}\text { Efficiency, } \\
\text { Speed }\end{array}$ & $\begin{array}{l}\text { Polite service, } \\
\text { Helpful staff }\end{array}$ & $\begin{array}{l}\text { Polite service, } \\
\text { Helpful staff }\end{array}$ & Uninterested \\
\hline Go to room & $\begin{array}{l}\text { Well laid out, } \\
\text { Executive } \\
\text { desk. } \\
\text { Bar room }\end{array}$ & $\begin{array}{l}\text { Luxurious } \\
\text { room, } \\
\text { Bar in room }\end{array}$ & $\begin{array}{l}\text { Nice setting, } \\
\text { Good view, } \\
\text { Bar in room }\end{array}$ & $\begin{array}{l}\text { Clear sign- } \\
\text { posting, } \\
\text { Well set out } \\
\text { room }\end{array}$ \\
\hline $\begin{array}{l}\text { Eat in } \\
\text { restaurant }\end{array}$ & $\begin{array}{l}\text { High quality } \\
\text { food with } \\
\text { speedy service }\end{array}$ & Quality food & $\begin{array}{l}\text { Quality of } \\
\text { experience }\end{array}$ & $\begin{array}{l}\text { Food served } \\
\text { hot, } \\
\text { Quality } \\
\text { experience }\end{array}$ \\
\hline $\begin{array}{l}\text { Go to } \\
\text { business } \\
\text { centre }\end{array}$ & $\begin{array}{l}\text { Very inter- } \\
\text { ested, } \\
\text { Fully serviced }\end{array}$ & Uninterested & Uninterested & Uninterested \\
\hline Go to sleep & $\begin{array}{l}\text { Comfortable } \\
\text { bed, } \\
\text { Quiet }\end{array}$ & $\begin{array}{l}\text { Comfortable } \\
\text { room, } \\
\text { Quiet }\end{array}$ & $\begin{array}{l}\text { Nice setting, } \\
\text { Quiet }\end{array}$ & Uninterested \\
\hline Check out & $\begin{array}{l}\text { Efficiency, } \\
\text { Instant atten- } \\
\text { tion }\end{array}$ & $\begin{array}{l}\text { Polite service, } \\
\text { Speed }\end{array}$ & $\begin{array}{l}\text { Polite service, } \\
\text { Speed }\end{array}$ & Uninterested \\
\hline
\end{tabular}

\section{EXAMPLES OF SERVICE PROCESS ENGINEERING}

Two examples will illustrate the way in which we handle the gap between the service delivery perspective and the customer satisfaction perspective. The presentation of that gap was vividly defined by the gap model for service delivery developed by PARASURAMAN et al. in 1985 (see Fig- 
ure 4). The gap model illuminated how the distance between customer expectations and customer satisfaction is inevitable through the way in which unknown expectations have to be converted into specifications which in the course of delivery become distorted by events and communications.

It might appear that the gap model provides impossible knowledge barriers to be overcome. However, interpreted correctly, the gaps are inevitable: they are there to be recognised, developed and exploited by the service system. In an engineering sense (a six sigma sense) the gaps propose impossibilities. In a service sense they are the magic of the process if they can be recognised and coped with. The machines of the service system must work the passage of the customer through the system so that service and productivity are both being provided for without compromise.

McDonald's achieve this with remarkable skill. The layout and organisation of the space demonstrate cleanliness and flow. The counter provides the one point of contact (and hence economies) of the system, making the queue visible from both the customer's and the provider's perspective. The visibility of the kitchen provides conspicuous evidence of cleanliness to the customers as well as access for the managers. To support the speed of the process the employee manning levels on the shifts are chosen to cope with peak loading to maintain employee tempo to match the culture of speed assumed by the customer. In the detailed process organisation no excess movement in needed. All this in accordance with the McDonald's proclaimed standards of "quality, service, cleanliness, value".

We thus reach a "requirement" of the service system - defined as the status or conditions of the delivery system - which can deliver satisfaction to customers consistently, possibly differentiated for different groups, in a reliable and profitable way!

It seems to be an insurmountable task to design a service delivery system that would deliver on the apparently conflicting, and each in itself difficult to achieve, requirements of transforming the customer expectations (which we do know precisely) into customer satisfaction (which is private to each individual customer) at a profit to the organisation. As we will demonstrate with examples, the task of designing an effective service delivery system, far from being a futile effort, does require a rare combination of engineering capability with a high tolerance for the uncertain.

What is needed is a careful consideration of the role of each of the service system elements at our disposal within the general context of a clearly specified service concept as translated into attributes of customer satisfaction. Furthermore, to strengthen the overall effect, it is necessary to identify and utilise any possibilities for interplay between the different elements of the system. By following this logic it is possible to arrive at a model of the service operation capable of delivering on all the requirements placed on it. 
CUSTOMER

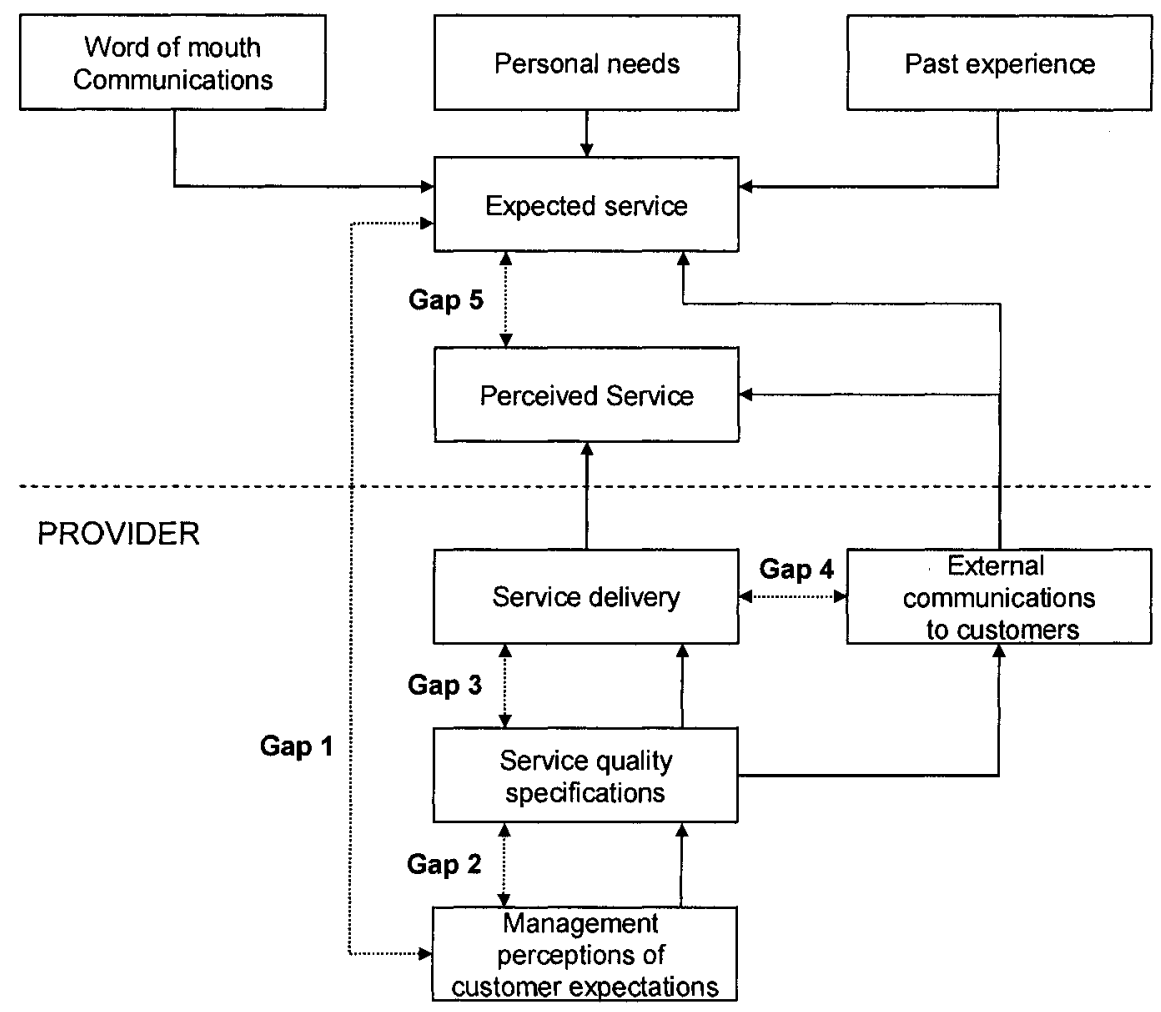

Figure 4. The Gap Model

(Source: PARASURAMAN et al. 1985, p. 43)

In the hospital system the design of adjacent facilities for operations and the involvement of all the staff in all processes unify the interfaces and motivations of both customers and employees. The support for the "country club" feeling in the hospital is underpinned by a rigid timing of procedures and encounters from entry to exit in which all uncertainties for the patient are removed by procedure itself thus removing an suppressing the principal customer worries. Queue management in both examples was avoided by "design". In McDonald's the queue is handled by rapidly adjustable staffing and flexibilities and always believing that it was preferable for the staff to wait (but not relax) than the customer (see Table 2). In the hospital queue control was managed at input to the facility by the management and prescreening of arrivals. 
Queue management, in its more general sense, takes the form of balancing the demand placed on the organisation by the customers with the supply capabilities (assets, people) of the organisation. Action can be taken on either side or both sides simultaneously to manage the trade-off between the quality of service provided as specified in the service offer the organisation communicates to the customers and the productivity requirement representing the pressure to serve the maximum number of customers and increase revenue.

Table 2. McDonald's Staffing

\begin{tabular}{|c|c|c|c|c|c|c|c|c|}
\hline & $\begin{array}{c}\text { Number } \\
\text { of } \\
\text { people }\end{array}$ & Grill & Windows & $\begin{array}{c}\text { Drive- } \\
\text { thru }\end{array}$ & Bin & Fry & Floaters & $\begin{array}{c}\$ \text { per hour } \\
\text { volume } \\
\text { guidelines }\end{array}$ \\
\hline \multirow[t]{7}{*}{ Minimum to open: } & 4 & 1 & 1 & 1 & - & - & 1 & 120 \\
\hline & 5 & 1 & 1 & 1 & - & - & 2 & 150 \\
\hline & 6 & 2 & 2 & 1 & - & - & 2 & 180 \\
\hline & 7 & 2 & 2 & 1 & - & - & 2 & 210 \\
\hline & 8 & 2 & 2 & 2 & 1 & - & 1 & 240 \\
\hline & 9 & 2 & 2 & 2 & 1 & - & 2 & 275 \\
\hline & 10 & 3 & 3 & 2 & 1 & - & 1 & 310 \\
\hline Fully staffed: & 17 & 5 & 5 & 3 & 1 & 1 & 2 & 645 \\
\hline
\end{tabular}

This is a delicate balance to manage, one which requires the separation of the concepts of revenue generation and profitability to the organisation, and a further distinction between the profit to the organisation and the 'profit' or value received as perceived by the customer. It is the concern with the maximisation of "profit" to both parties that ensures the success of capacity management efforts, as is well illustrated by the example of the hernia hospital's careful consideration of the implications of demand and supply policies on both the net profit to the organisation and the preservation of the service concept (see Table 3 ).

\section{IDENTIFYING SUCCESS IN THE DESIGN OF A SERVICE}

The successful linking of the service delivery system with the customer experience system has been proposed as a careful interweaving of customer processing and facilities architecture as worked by employees. We have proposed that despite the indirect nature of the relationship, it is still advanta- 
geous to approach the service provision through a "design" approach. The broad pattern of the links is

\begin{tabular}{|c|c|c|}
\hline Service promise & $\rightarrow$ Service experience & $\rightarrow$ Value for money \\
\hline Service system design & $\rightarrow$ Service delivery by employees & $\rightarrow \begin{array}{l}\text { Cost-effective } \\
\text { outcome }\end{array}$ \\
\hline
\end{tabular}

These two streams of translation must work coherently to mutual advantage whilst being fundamentally different! The push for cost effectiveness will classically inhibit service delivery. Equally, the demands of a customer if fulfilled to the letter will destroy the economies of the operation. Success is therefore not at all measured by "profitability". It is not measured simply by sales and the trends on costs. Success means that the design of the system, as worked by the employees and as experienced by the customers, is in fact economic and efficient to both parties. Nor should satisfaction be measured by customer complaints or employee contribution be measured by hours. The real test of the service system requires a view of the right working of the service provision to be defined and this view to be testable and tested.

This reverses the classic role of service value as embodied by customers. It proposes that there is a view on the means through which the service system can deliver the elements of satisfaction and the appraisal by the organisation of success should be measured in terms of the ability to meet those targets. It means that we measure our ability to inspect the design on the one hand and are able to explain "profit" for the customer separately from profit for the service provider.

Such a position is well illustrated in McDonald's, where a store inspection sheet verifies that:

- evidence that the service value elements can be delivered is provided in a store visit report (see Table 4);

- the planning of the staffing system is proven by the ability to forecast;

- the provision of assets, facilities, and space is never the restriction on capacity requirements;

- the profitability of the delivered items is ignored in favour of an explanation of how relative value-added and cost is perceived by the customer as the basis for pricing.

Similarly, in the case of the hospital, "inspection" was of the ability to do the job, not on the outcome and the profitability for the patient was evaluated alongside profitability for the hospital. 
Table 3. Managing demand and supply - the hernia hospital.

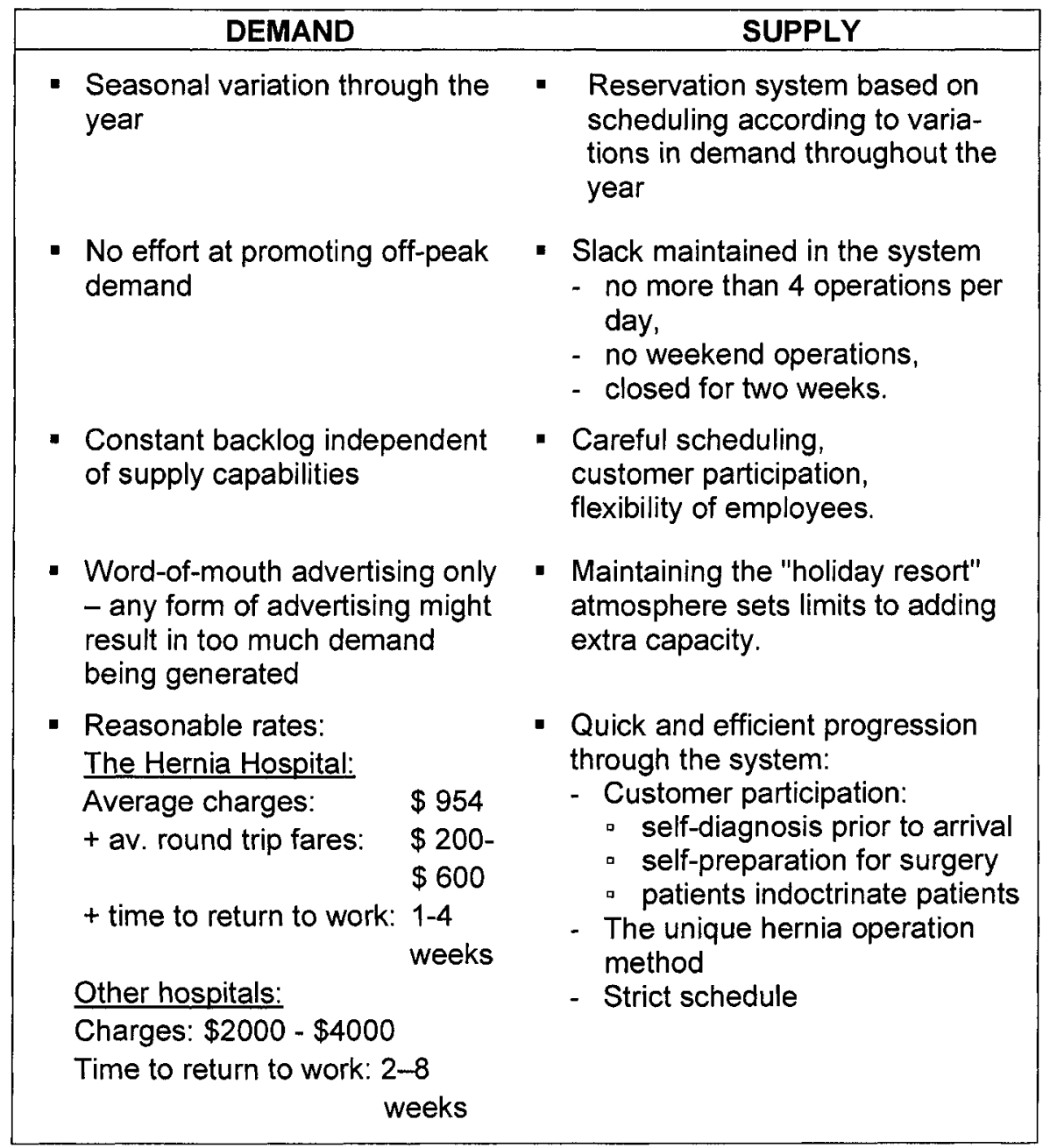

Service can thus be provided through design principles and the success of the service design should be judged against the inputs of design intentions, not simply the outputs realised. This provides service engineers with a rich set of aims in all organisations in searching for the appropriate ways to deliver the vaguer elements of service as distinct from production.

When this is done well, the real value to the customer will be recognised by driving up demand and demand predictability through repeat buying and justifying higher prices. Equally, on the costing side we must only consider 
the total service system cost in valuing the provision on service and not disaggregate the elements of delivery and elements of cost into a fragmented analysis which will prevent understanding of the total experience engaged by the customer.

Table 4. McDonald's: Store visitation report (extract)

\begin{tabular}{|l|c|}
\hline Service & Points \\
\hline $\begin{array}{l}\text { 1. Management in backup position, following proper } \\
\text { procedures, expediting service }\end{array}$ & 3 \\
$\begin{array}{l}\text { 2. Service atmosphere - smiles, hustle, teamwork, neat } \\
\text { appearance }\end{array}$ & 3 \\
$\begin{array}{l}\text { 3. Greeting, order assembly, presentation, thank you, and } \\
\text { asking for repeat business }\end{array}$ & 3 \\
$\begin{array}{l}\text { 4. Service accuracy - order accurately filled, change accurately } \\
\text { made }\end{array}$ & 3 \\
\hline Cleanliness, Merchandising, Outside & Points \\
\hline $\begin{array}{l}\text { 1. Neighborhood - free of litter (1 block in each direction) } \\
\text { 2. Landscaping - free of litter and well maintained }\end{array}$ & 1 \\
3. Painted surfaces - in good condition and clean \\
4. Parking lot - free of litter, clean, seal and stripe in good \\
$\begin{array}{l}\text { condition } \\
\text { 5. Waste receptacles - clean, good repair and emptied as } \\
\text { needed }\end{array}$ & 1 \\
$\begin{array}{l}\text { 6. Sidewalks - clean, sealed, and free of hazardous conditions } \\
\text { 7. Windows and doors - glass and all associated areas clean }\end{array}$ & 1 \\
\hline
\end{tabular}

\section{REFERENCES}

FITZSIMMONS, J.A.; FITZSIMMONS, M.J.:

Service Management for Competitive Advantage.

New York, NY: McGraw-Hill, 1994.

JOHNSTON, R.; SLACK, N. D. C. (eds.):

Service Operations: The Design and Delivery of Effective Service Operations.

Warwick: Warwick Printing, 1993.

JOHNSTON, R.; CLARK, G.:

Service Operations Management.

London: Financial Times Prentice Hall, 2001. 
LOVELOCK, C. H.:

Managing Services.

Upper Saddle River, NJ: Prentice Hall, 1992.

PARASURAMAN, A.; ZEITHAML, V. A.; BERRY, L. L.:

A conceptual model of service quality and implications for further research.

In: Journal of Marketing,

Chicago, IL, 49(1985)3, pp. 41-50.

SLACK, N.; CHAMBERS, S.; HARLAND, C.; HARRISON, A.; JOHNSTON, R.:

Operations Management.

London: Pitman, 2nd ed., 1998. 